\title{
Cerebral perfusion and psychometric testing in military amateur boxers and controls
}

\author{
P M Kemp, A S Houston, M A Macleod, R J Pethybridge
}

\begin{abstract}
The objective was to compare two neurophysiological variables in active amateur boxers with non-boxing sportsmen. 41 boxers and 27 controls were given psychometric tests: 34 boxers and 34 controls underwent technetium-99m hexamethylpropyleneamineoxime single photon emission computerised tomography (Tc99m HMPAO SPECT) cerebral perfusion scans. The controls performed better at most aspects of the psychometric tests. Boxers who had fought fewer bouts had a tendency to perform better at psychometric tests than those boxers who had fought more bouts. Tc-99m HMPAO SPECT cerebral perfusion scanning showed that controls had less aberrations in cerebral perfusion than the boxers.

In conclusion, significant differences were shown in two neurophysiological variables between young amateur sportsmen who box and those who do not. The long term effects of these findings remain unknown.
\end{abstract}

(F Neurol Neurosurg Psychiatry 1995;59:368-374)

Keywords: boxing; psychometrics; SPECT

The "punch drunk syndrome"-dementia pugilistica-embodies the chronic sequela of boxing and has certain features in common with Alzheimer's dementia and Parkinson's disease. $^{1-3}$ For over 25 years it has been known that professional boxing is associated with this debilitating neurological disease ${ }^{1}$; however, there is considerable controversy about the long term effects of amateur boxing. Dementia pugilistica is characterised by disorders of movement-a consequence of damage to pyramidal, extrapyramidal, and cerebellar pathways-and the dementia is secondary to widespread damage throughout the brain. Mechanisms of damage include contusion, shearing forces on nerves and vessels, and diffuse amyloid deposition of amyloid protein. Immunohistochemical staining of this amyloid has clearly shown the histological similarities of the punch drunk syndrome with Alzheimer's dementia. ${ }^{34}$

The few studies in the scientific literature that assess the safety of amateur boxing produce conflicting results. ${ }^{5-14}$ Extracting the data from mixed studies on amateur and professional boxers generally shows adverse findings in the amateur boxers, ${ }^{15}{ }^{18}$ but numbers studied were too small (under 10) to derive substantive conclusions.

A diversity of investigations have been undertaken to detect subtle neurological impairment in fit amateur boxers, including CT, MRI, EEG, evoked potentials, and psychometric testing. This reflects a lack of consensus among investigators as to which is the most appropriate test to use, if any. Furthermore, most studies are compromised to a varying degree by selection bias, absence or lack of appropriate controls, the presence of extraneous head injuries inflicted outside the ring, and multiple investigatory procedures that increase the possibility of chance findings.

Amateur boxing is encouraged in the armed forces to promote fitness and self discipline. To ascertain whether boxers representing the Royal Navy and Army boxing associations exhibit signs of subtle neurological abnormalities, this prospective study was undertaken to compare a group of amateur boxers with appropriate servicemen controls. From the gamut of procedures available for investigating the effects of closed head injury-the potential insult encountered in boxing - it was decided to use psychometric tests and technetium-99m hexamethylpropyleneamineoxime single photon emission computerised tomography (Tc-99m HMPAO SPECT) cerebral perfusion imaging. The Tc99m HMPAO SPECT provides information on regional cerebral perfusion, but by itself does not provide an absolute measurement of blood flow. The tomographic images produced are akin to those obtained by PET, which determines cerebral blood flow with ${ }^{15} \mathrm{O}_{2} .{ }^{1920}$ As ischaemic pathophysiological changes are known to occur after closed head injury, ${ }^{21} 22$ it is only to be expected that cerebral perfusion imaging of the brain with Tc99m HMPAO SPECT will be more sensitive in showing the early subtle abnormalities than the subsequent structural changes, if any, that may be detected by CT or MRI. ${ }^{23} 24$

\section{Methods}

SELECTION OF BOXERS

Amateur boxers who represent either the Royal Navy or Army boxing associations were invited to participate in this study. At the time of request all the amateur boxers who represented their respective services volunteered and gave informed consent, thus minimising selection bias. None of the boxers had sus- 
tained a relevant head injury outside the ring (defined as more than momentarily loss of consciousness or concussion lasting more than a minute) or had a history of neurological illness. Most of the boxers underwent both psychometric tests and Tc-99m HMPAO SPECT brain scanning; however, due to logistical constraints a few boxers were not able to have both investigations. In total 42 boxers participated in the trial. Forty one boxers underwent psychometric tests of which 33 also had Tc99m HMPAO SPECT scans; one boxer underwent Tc-99m HMPAO SPECT without psychometric testing. The boxers varied in age from 18 to 30 years, number of competitive bouts fought ranged from 0 to 250 (median 40 ), and duration of participation in boxing was from three months to 17 years.

\section{SELECTION OF CONTROLS}

Servicemen undergoing medical assistant training were invited to participate as controls in the study. Criteria for selection included age 18-30 years, regular participation in amateur sports, no history of relevant head injury (as defined for the boxers), no history of neurological illness, and no previous participation in boxing. In total, 34 controls underwent Tc99m HMPAO scanning and a further 27 controls did the psychometric tests.

\section{TC-99M HMPAO SPECT SCANNING TECHNIQUE} AND INTERPRETATION OF IMAGE

All subjects had $550 \mathrm{MBq}$ of $\mathrm{Tc}-99 \mathrm{~m}$ HMPAO injected intravenously into an antecubital vein in a dimly lit room and were scanned within 10 minutes of injection with a Siemens 7500 ZLC tomographic camera with a low energy all purpose collimator linked to a Bartec Micas V Sun System. Data were acquired for 15 seconds from each of 64 angles into a $140 \mathrm{keV}+10 \%$ window. Filtered back projection was performed with a soft Shepp-Logan filter and the data stored as 64 axial slices of $64 \times 64$ matrices. The images produced of the boxers and controls were compared with an "atlas of normality" to detect focal abnormalities. The atlas of normality was derived from the images of 50 healthy male and female subjects, civilian and military personnel, who were aged 18-60 years and had no history of head injury or neurological illness. These 50 images were registered with respect to a reference image ${ }^{25}$ and normalised to the cerebellar counts. The normal atlas was created with a mean and several principal component images after registration and normalisation. ${ }^{26}$ The resolution of the mean and component images was maintained at the voxel level of the original images. The principal component images correspond to the most significant patterns of variation in the 50 images, and it was found that six components were necessary to provide an adequate description of normal variation. The registered normalised images of the 34 boxers and 34 controls were then compared automatically to the atlas of normality. ${ }^{2627}$ The significance (in normal SDs) of voxels with reduced perfusion in the cortical region was calculated. An image was defined as abnormal if it contained at least one deficit with 10 connected voxels above a threshold of 2.9 SDs.

\section{PSYCHOMETRIC TESTS}

The battery of tests selected assessed a wide range of cognitive functions ${ }^{28}$ (reaction time, psychomotor learning, reasoning, perception and comparison, short term memory, and motor function). The test battery included the following tasks:

\section{Four choice reaction time}

Four boxes numbered 1-4 are displayed on the screen and one of the boxes is highlighted. The participant has to strike the appropriate numerical key. The mean response latency for correct answers was recorded (the greater the time the slower the response).

\section{Code substitution}

The code consists of nine letters and corresponding numbers displayed across the top of the screen. Underneath the code rows of letters are displayed and the participant has to insert the appropriate number. The number of letters correctly encoded was recorded.

\section{Logical reasoning}

Logical statements are presented on the screen and the participant has to decide whether these statements are true or false. Statements can be expressed in the affirmative or negative. Verbs include "trails", "follows", and "precedes". The percentage of statements correctly answered was recorded.

\section{Simultaneous pattern comparison}

Pairs of patterns are displayed simultaneously on the screen; the participant has to decide whether these are the same or different. The number of correct answers was recorded.

\section{Sternberg}

Four numbers are displayed on the screen for one second. Subsequently, pairs of numbers are displayed and the participant has to decide whether at least one of the pair of numbers was represented in the original set of four numbers. The mean response latency time for correct answers was recorded-that is, the greater the time the slower the response.

\section{Finger tapping}

The participant has to press two adjacent keys with the index and middle finger of the nondominant hand. The number of alternate presses was recorded.

The automated test battery was given by an experienced person. All tasks were assessed over a two minute period except for the alternate finger tapping, which lasted for $30 \mathrm{sec}-$ onds. Forty one boxers and 27 controls had three practice attempts at each of the tests before the main run. A Zenith lap top computer was used throughout the study and all tests were undertaken in a quiet, well lit, and warm room. Ability at some aspects of psychometric testing can be influenced by age and a 
subject's intellect; ${ }^{29}$ consequently, it may be necessary to adjust for these factors. It was decided to use school attainment in the form of number of $O$ level examinations passed as a marker of intellect. Statistical modelling would show whether age and intellect would be suitable as covariates in the analysis.

This study received approval from the Royal Naval clinical research scientific committee (military), the local ethics committee (civilian), and the administration of radioactive substance advisory committee. All volunteers gave informed written consent.

\section{Results}

AGE AND SCHOOL ATTAINMENT

Table 1 shows the summary of the data of the distributions of the ages and number of $O$ levels for the amateur boxing and control groups. Applying the Kolmogorov-Smirnov test to these cumulative distributions for the groups of boxers and controls showed no significant differences (Kolmogorov-Smirnov test $P>0 \cdot 1)$.

TC-99M HMPAO SCANNING

Initial data exploration (Zelen test) showed that the scan findings (normal or abnormal)

Table 1 Summary data of the distributions of the ages and number of $O$ levels for the amateur boxing and control groups undergoing Tc-99m HMPAO SPECT and psychometric testing

\begin{tabular}{lcccc}
\hline & No & Mean (SD) & Minimum & Maximum \\
\hline Age: & \multicolumn{3}{c}{$T c-99 m$ HMPAO SPECT } \\
$\quad$ Boxers & 34 & $22 \cdot 0(2 \cdot 9)$ & 18 & 29 \\
$\quad$ Controls & 34 & $22 \cdot 2(3 \cdot 1)$ & 18 & 29 \\
O levels: & & & & \\
$\quad$ Boxers & 34 & $1 \cdot 9(2 \cdot 6)$ & 0 & 8 \\
Controls & 34 & $3 \cdot 1(2 \cdot 8)$ & 0 & 9 \\
& & Psychometric testing & \\
Age: & & & \\
$\quad$ Boxers & 41 & $22 \cdot 0(2 \cdot 8)$ & 18 & 29 \\
$\quad$ Controls & 27 & $22 \cdot 0(2 \cdot 9)$ & 18 & 29 \\
O levels: & & $2 \cdot 4(3 \cdot 1)$ & 0 & 8 \\
$\quad$ Boxers & 41 & $2 \cdot 1(2 \cdot 6)$ & 0 & 9 \\
$\quad$ Controls & 27 & $3 \cdot 1(2 \cdot 6)$ & \\
\hline
\end{tabular}

Table 2 Results of comparing HMPAO SPECT of amateur boxers and controls with the "atlas of normality"

\begin{tabular}{llll}
\hline & \multicolumn{4}{l}{ HMPAO SPECT } \\
\cline { 2 - 4 } & Normal & Abnormal & Total \\
\hline Boxers & 20 & 14 & 34 \\
Controls & 29 & 5 & 34 \\
\hline
\end{tabular}

Table 3 Average psychometric test scores for 41 boxers and 27 controls without adjustment for covariates

\begin{tabular}{|c|c|c|c|}
\hline Psychometric test & Group & Mean & $\begin{array}{l}\text { ( } 95 \% \text { CI for difference of } \\
\text { means (boxers - controls) }\end{array}$ \\
\hline Four choice reaction time & \multirow{5}{*}{$\begin{array}{l}41 \text { boxers } \\
27 \text { controls } \\
41 \text { boxers } \\
27 \text { controls } \\
41 \text { boxers } \\
27 \text { controls } \\
41 \text { boxers } \\
27 \text { controls } \\
41 \text { boxers } \\
27 \text { controls }\end{array}$} & \multirow{5}{*}{$\begin{array}{c}0.49 \mathrm{~s} \\
0.42 \mathrm{~s} \\
46.5 \text { correct } \\
51.2 \text { correct } \\
89.9 \text { correct } \\
99.7 \text { correct } \\
1.18 \mathrm{~s} \\
1.11 \mathrm{~s} \\
90 \text { taps } \\
113 \text { taps }\end{array}$} & $(0.04 \text { to } 0.10)^{\star}$ \\
\hline Code substitution & & & $(-8 \cdot 3 \text { to }-1 \cdot 1)^{\star}$ \\
\hline Pattern recognition & & & $(-17 \cdot 6 \text { to }-2 \cdot 0)^{\star}$ \\
\hline Sternberg reaction time & & & $(0.0$ to 0.2$)$ \\
\hline Alternate finger tapping & & & $(-33 \text { to }-13)^{\star}$ \\
\hline
\end{tabular}

were not influenced by age or school attainment. Table 2 shows the summary of the results of Tc-99m HMPAO SPECT scanning for the groups of boxers and controls. Abnormality is defined as the presence of one or more regions of significant aberration in cerebral perfusion when compared with the atlas of normality. It can be seen that $41 \%$ of the amateur boxers had abnormal scans, compared with $14 \%$ of the controls $\left(\chi^{2}=5.9\right.$, $\mathrm{df}=1, \mathrm{P}<0.02)$. In the control group the aberrations in cerebral perfusion were largely singular whereas in the boxing group the aberrations were generally multiple. In both groups there were no predominant sites of abnormality, the lesions were scattered throughout the cerebral cortex.

\section{PSYCHOMETRIC TESTING}

Table 3 shows the average psychometric test scores of the raw data (before transformation or introduction of covariates) for the groups of boxers and controls. The logical reasoning task had to be excluded from the analysis as many boxers and several controls had scores around $50 \%$. This suggested that those subjects found the task too difficult and were guessing. The distributions of the scores for the code substitution, pattern recognition, and finger tapping tasks for each group of boxers and controls were found to be normal by univariate and multivariate analysis. The results of the reaction time and Sternberg tasks required reciprocal transformations to satisfy normality assumptions in the statistical models considered.

UNIVARIATE ANALYSIS OF VARIANCE (ANOVA) The results of a univariate ANOVA show that in all psychometric tests analysed the boxers performed less well, on average, than the controls. In four of the five tests these differences ranged from $10-20 \%$ and were significant $(P<0.05)$.

\section{UNIVARIATE ANALYSIS OF COVARIANCE (ANCOVA)}

Linear modelling testing of the data (or transformed data) for each psychometric test with main effects for age, age squared, number of $O$ levels and group (boxer or control), and interactions between group and education, group and age, and group and age ${ }^{2}$, indicated that the covariates (age, age ${ }^{2}$, and number of $O$ levels) should be included in the model. Also, the interaction terms could be excluded as they had no significant influence on the psychometric tests.

Table 4 shows a summary of the average psychometric test scores (untransformed) with the adjustment for the covariates. In four out of the five tasks there were significant differences between the groups to the detriment of the boxers. These differences ranged from $10-20 \%$.

\section{COMPARISON OF BOXERS WITH A LOW AND} HIGH NUMBER OF BOUTS

The median number of bouts fought can be used to divide the boxers into two groups; 21 
Table 4 Summary of average psychometric test scores for 41 boxers and 27 controls adjusted for covariates (age, age $e^{2}$ number of $O$ levels)

\begin{tabular}{|c|c|c|c|}
\hline Psychometric test & Group & Mean & $\begin{array}{l}\text { (95\% CI for difference of } \\
\text { means (boxers - controls) }\end{array}$ \\
\hline Four choice reaction time & $\begin{array}{l}41 \text { boxers } \\
27 \text { controls }\end{array}$ & $\begin{array}{l}0.49 \mathrm{~s} \\
0.42 \mathrm{~s}\end{array}$ & $(0.04 \text { to } 0 \cdot 10)^{\star}$ \\
\hline Code substitution & $\begin{array}{l}41 \text { boxers } \\
27 \text { controls }\end{array}$ & $\begin{array}{l}46.6 \text { correct } \\
51.0 \text { correct }\end{array}$ & $(-8.0 \text { to }-0.9)^{\star}$ \\
\hline Pattern recognition & 41 boxers & $\begin{array}{l}90.2 \text { correct } \\
99.1 \text { correct }\end{array}$ & $(-15 \cdot 7 \text { to }-2 \cdot 1)^{\star}$ \\
\hline Sternberg reaction time & $\begin{array}{l}41 \text { boxers } \\
27 \text { controls }\end{array}$ & $\begin{array}{l}1.17 \mathrm{~s} \\
1.12 \mathrm{~s}\end{array}$ & $(-0.1$ to 0.2$)$ \\
\hline Alternate finger tapping & $\begin{array}{l}41 \text { boxers } \\
27 \text { controls }\end{array}$ & $\begin{array}{r}90 \text { taps } \\
113 \text { taps }\end{array}$ & $(-32 \text { to }-12)^{\star}$ \\
\hline
\end{tabular}

$\star \mathrm{P}<0.05$.

Table 5 Summary of average psychometric test scores for 21 low bout boxers and 20 high bout boxers adjusted for covariates (age, age ${ }^{2}$, number of $O$ levels)

\begin{tabular}{|c|c|c|c|}
\hline Psychometric test & Group & Mean & $\begin{array}{l}\text { (95\% CI for difference of } \\
\text { means (low - high bouts) }\end{array}$ \\
\hline Four choice reaction time & \multirow{4}{*}{$\begin{array}{l}21 \text { low bout } \\
20 \text { high bout } \\
21 \text { low bout } \\
20 \text { high bout } \\
21 \text { low bout } \\
20 \text { high bout } \\
21 \text { low bout } \\
20 \text { high bout }\end{array}$} & \multirow{4}{*}{$\begin{array}{l}0.46 \mathrm{~s} \\
0.52 \mathrm{~s} \\
48.3 \text { correct } \\
44.6 \text { correct } \\
94.2 \text { correct } \\
85.3 \text { correct } \\
88 \text { taps } \\
92 \text { taps }\end{array}$} & $(-0.10 \text { to }-0.01)^{\star}$ \\
\hline Code substitution & & & $(-1 \cdot 3$ to $-8 \cdot 7)$ \\
\hline Pattern recognition & & & $(0 \cdot 7 \text { to } 17 \cdot 1)^{\star}$ \\
\hline Alternate finger tapping & & & $(-16 \cdot 0$ to $8 \cdot 6)$ \\
\hline
\end{tabular}

$\star \mathrm{P}<0.05$. had endured minimal head trauma but subsequently died from other than cranial causes have shown microglial scars. ${ }^{31}$ Also, psychometric testing has been shown to elicit the detrimental effects of cumulative concussion. ${ }^{32}$ Consequently, it is not surprising that some think that the term "commotio cerebri"-brief loss of consciousness without permanent brain damage-should be discarded. ${ }^{21}$

Given the ischaemic pathophysiological changes found in closed head injury ${ }^{21} 22$ it is not surprising that functional brain imaging with Tc-99m HMPAO SPECT scanning is more sensitive than CT or MRI at showing the consequences of closed head injury. ${ }^{2324}$ Cerebral amyloid protein deposition, immunohistochemically similar to that seen in Alzheimer's disease, has been noted in the brains of ex-boxers ${ }^{34}$ and in people with head trauma. ${ }^{33}$ Most importantly, it has also been shown that these regions of amyloid protein deposition are associated with abnormal vasculature, ${ }^{34}$ which could also account for the abnormalities noted on Tc-99m HMPAO SPECT cerebral perfusion imaging.

The development of a computer program to detect aberrations in Tc-99m HMPAO SPECT cerebral perfusion imaging removes the potential for human bias. This program uses a multivariate technique to assess cerebral perfusion. Similar techniques have been applied to the interpretation of PET scans that show cerebral metabolism. ${ }^{35-37}$ Computer analysis of the images in this study showed five of the 34 controls to have aberrations in cerebral perfusion patterns giving a specificity of $85 \%$. This value compares favourably with the specificity of $84 \%$ noted by PET scanning. ${ }^{38}$ Comparing the cerebral perfusion patterns of the amateur boxers with the controls in our study showed a significantly greater proportion of aberrations in the cerebral perfusion patterns of boxers than in the controls.

Although there was not a significant difference between the psychometric test scores of the 13 boxers with abnormal cerebral perfusion and the 20 boxers with normal scans $(P=0.2)$ this was not unexpected. Firstly, the numbers were small, and secondly, HMPAO cerebral perfusion imaging and psychometric testing are assessing different aspects of neurophysiology. It is only to be expected that, in the detection of subtle neurological abnormalities, focal cerebral perfusion deficits may occur in areas of the cerebral cortex that are not required for the cognitive tasks of psychometric testing. In overt neurological disease-for example, patients with Alzheimer's disease or severe head injury - the results of HMPAO cerebral perfusion imaging and psychometric testing (and other neurological investigations) are more likely to show concordance. ${ }^{39-41}$ It is arguable whether the same controls that underwent psychometric testing should also have had the HMPAO brain scans. At the outset of this trial the main consideration was to compare two groups of sportsmen (boxers and non-boxers). Consequently, it was logistically easier to 
recruit separate control groups. Given the relatively high specificity of HMPAO brain scanning, $85 \%$ in this study, it would have required considerably more controls (and ethical deliberations) to undertake a study of sufficient power to compare HMPAO cerebral perfusion imaging with psychometric testing in young healthy adults.

Psychometric testing is a highly sensitive investigation for detecting the subtle cognitive impairment after head injury. ${ }^{32}{ }^{2}$ When using psychometric testing in a group comparative study it would seem appropriate to recruit controls of a similar age, intellectual ability, and possibly other social factors. In this study we recruited controls who were sports playing servicemen who were of a similar age and had attained similar educational qualifications. Intelligence has been shown to correlate moderately with some psychometric tests ${ }^{29}$ (the correlation coefficient being of the order of $0 \cdot 5)$. A similarly significant correlation has been shown between school attainment and intelligence; ${ }^{43}$ thus it was decided to use school attainment as a potential marker of intellect. Obviously, in any group comparative study it is preferable to match for important variables beforehand rather than control statistically for differences subsequently. A straight forward comparison of the psychometric test scores of the groups of boxers and controls, without the introduction of covariates, showed significant differences between the groups in four of the five psychometric tests to the detriment of the boxers. Statistical modelling of the psychometric test scores showed that the covariates of age, age ${ }^{2}$, and school attainment should be introduced in the model. Statistical analysis with these covariates included showed almost identical results to the analysis without covariates-namely, in four out of five tests the boxers performed significantly worse. The similarity of the results of these different types of analyses (with and without covariates) was not unexpected given the similar distributions of ages and school attainment of the two groups. Furthermore, although on average the controls had achieved slightly, but not significantly, better at school, the introduction of the covariates would have adjusted the boxers psychometric test results favourably relative to those of the controls. It cannot be completely excluded that the introduction of a more formal measure of intellect (as defined by detailed intelligence assessment) as a further covariate, as well as age, age $^{2}$, and number of $O$ levels, would have accounted for some of the residual variance in the model. Similarly, it could be argued that other covariates should have been assessed-for example, social class of participant's mother (this could reflect educational opportunity) or even amount of time participating in computer games (a task not too dissimilar to automated psychometric testing). At the outset of this trial it was the intention of the investigators to minimise the time required by the boxers and controls to undergo the investigations. There is no doubt that the additional introduction of formal evaluation of intelligence would have reduced the numbers who volunteered with the consequent introduction of a selection bias. Unfortunately, in all scientific studies that require volunteers, there will always have to be a trade off between the components of the potential biases in the methodology.

Butler et $a l^{13}$ have recently published the findings of a United Kingdom study comparing the psychometric test scores of 86 amateur boxers with those of 31 water polo players and 47 rugby union players. Comparing the results of the boxers with those of the controls without the introduction of any covariates showed that the boxers performed worse on all 12 psychometric tests; in eight of these tests the differences were significant. The authors noted that many of the boxers were early school leavers whereas a proportion of the rugby and water polo players were undergraduates; consequently, a definitive analysis could not be undertaken as no estimates were available for intellect. In the absence of being able to analyse the psychometric data, and given that other neurological investigations gave negative results, the investigators concluded that "no evidence of neuropsychological dysfunction due to boxing could be found". Surely it would have been more appropriate to have selected controls of a similar scholastic level rather than attempt to adjust the psychometric test scores statistically (even if appropriate data had been collected) for what seems to be two groups of widely differing intellectual ability?

In our study the number of bouts correlated highly with the number of years of boxing. Consequently either variable could be used as a measure of boxing exposure. The group of boxers could be divided around the median number of bouts into those with less than and those with more than 40 bouts. Univariate and multivariate analyses of covariance showed differences in cognitive performance between the two groups to the detriment of those boxers in the over 40 bout group. These findings could also be shown by significant inverse trends in certain aspects of psychometric testing and number of bouts fought. Similar findings were noted by Stewart et al. ${ }^{14}$ This prospective American study conducted between 1986 and 1990 spent $\$ 1.5$ million in examining 484 amateur boxers over a four year period. Statistical modelling of the psychometric data in the American study showed that age, age $^{2}$, and education, together with other covariates could be used in the model. It is interesting that common covariates were noted in this and our study. Psychometric testing of the 484 amateur boxers on entry to the study showed significant tests of trend between the total number of bouts fought and ability in psychometric testing. Although follow up testing on 393 of the boxers over a two year period did not show any deterioration in psychometric performance, the investigators urged caution in the interpretation of this finding as a longer latency period may be required before effects are manifested. Similarly, Butler et $a l^{13}$ did not show any deterioration in their boxers on 
Table 6 Major studies assessing the safety of amateur boxing

\begin{tabular}{|c|c|c|c|}
\hline Investigators & Participants & Findings & Comments \\
\hline $\begin{array}{l}\text { Thomassen et al }{ }^{5} \\
\text { DENMARK } 1979\end{array}$ & $\begin{array}{l}53 \text { former boxers } \\
53 \text { footballers }\end{array}$ & $\begin{array}{l}\text { No significant differences on clinical } \\
\text { examination, EEG, or psychometric } \\
\text { testing. }\end{array}$ & $\begin{array}{l}\text { These findings are confounded by the } \\
\text { fact that } 88 \% \text { of the controls and } 75 \% \\
\text { of the boxers sustained head injuries } \\
\text { outside the ring. }\end{array}$ \\
\hline $\begin{array}{l}\text { McLatchie et } a l^{6} \\
\text { SCOTLAND } 1987\end{array}$ & $\begin{array}{l}20 \text { active boxers } \\
\text { Variable number } \\
\text { of controls }\end{array}$ & $\begin{array}{l}\text { Abnormal clinical examination in } 35 \% \\
\text { of boxers, abnormal EEG in } 40 \% \text { of } \\
\text { boxers, abnormal psychometric testing } \\
\text { in } 63 \% \text { of boxers. }\end{array}$ & $\begin{array}{l}\text { No controls had clinical examination } \\
\text { or EEG. University staff used as } \\
\text { controls for psychometric testing. }\end{array}$ \\
\hline $\begin{array}{l}\text { Brooks et } a l^{7} \\
\text { SCOTLAND } 1987\end{array}$ & $\begin{array}{l}29 \text { active boxers } \\
19 \text { controls }\end{array}$ & $\begin{array}{l}\text { No significant differences on } \\
\text { psychometric testing. }\end{array}$ & $\begin{array}{l}\text { Only } 39 \% \text { of invited boxers } \\
\text { participated. Controls matched for age, } \\
\text { education, and ethnicity. }\end{array}$ \\
\hline $\begin{array}{l}\text { Haglund et } a l^{9-12} \\
\text { SWEDEN } 1990\end{array}$ & $\begin{array}{l}50 \text { former boxers } \\
50 \text { athletes }\end{array}$ & $\begin{array}{l}\text { No significant differences on clinical } \\
\text { examination, CT, MRI. EEG showed } \\
\text { significantly greater abnormalities in } \\
\text { boxers. }\end{array}$ & $\begin{array}{l}\text { Although the authors concluded that } \\
\text { amateur boxing appeared "safe" the } \\
\text { differences on EEG examination } \\
\text { remain unexplained. }\end{array}$ \\
\hline $\begin{array}{l}\text { Butler et al }{ }^{13} \\
\text { ENGLAND } 1993\end{array}$ & $\begin{array}{l}86 \text { active boxers } \\
31 \text { water polo and } \\
47 \text { rugby players }\end{array}$ & $\begin{array}{l}\text { Significant differences between boxers } \\
\text { and controls on initial psychometric } \\
\text { testing to the detriment of the boxers. } \\
\text { Improvement noted on longitudinal } \\
\text { assessment. No differences on clinical } \\
\text { examination, evoked responses, EEG, } \\
\text { CKBB isoenzymes, or ophthalmological } \\
\text { assessment. }\end{array}$ & $\begin{array}{l}\text { No allowance for the intellectual } \\
\text { differences between the controls (some } \\
\text { were university students) and the } \\
\text { boxers (many early school leavers). } \\
\text { Authors concluded no evidence of } \\
\text { damage in boxers. }\end{array}$ \\
\hline $\begin{array}{l}\text { Stewart et } a l^{14} \\
\text { USA } 1994\end{array}$ & 484 amateur boxers & $\begin{array}{l}\text { Significant tests of trend between } \\
\text { psychometric testing ability and } \\
\text { number of bouts. No deterioration on } \\
2 \text { year follow up. }\end{array}$ & $\begin{array}{l}\text { Authors urge caution in the } \\
\text { interpretation of the longitudinal } \\
\text { findings as a longer latency period may } \\
\text { be required before effects are manifest. }\end{array}$ \\
\hline $\begin{array}{l}\text { Kemp et al } \\
\text { ENGLAND } 1994 \\
\text { (This study) }\end{array}$ & $\begin{array}{l}\text { (i) } 34 \text { active boxers } \\
34 \text { controls } \\
\text { (ii) } 41 \text { active boxers } \\
27 \text { controls }\end{array}$ & $\begin{array}{l}\text { Boxers had significantly more } \\
\text { abnormalities on Tc-99m HMPAO } \\
\text { cerebral perfusion imaging. } \\
\text { Psychometric testing revealed boxers } \\
\text { to perform significantly worse than } \\
\text { controls and, in addition, those boxers } \\
\text { with the greater number of bouts } \\
\text { performed significantly worse than } \\
\text { those with few bouts. }\end{array}$ & $\begin{array}{l}\text { All invitees participated thus reducing } \\
\text { selection bias. Subjects with } \\
\text { extraneous head injuries were not } \\
\text { included. Controls matched for age } \\
\text { and education. }\end{array}$ \\
\hline
\end{tabular}

longitudinal assessment over an undisclosed period. They did note that "any effects due to boxing would have had to be large to be detected against the background of premorbid variation in ability". Unfortunately, they did not have any data available for "estimates of intellectual capacity".

Table 6 lists the results of recent major studies that assessed the safety of amateur boxing. It can be seen that our study has been relatively more fortunate than most in terms of selection bias, extraneous head injuries, and choice of controls.

In summary, psychometric testing and Tc99m HMPAO cerebral perfusion imaging were undertaken in a group of service amateur boxers and a control group of sportsmen. Psychometric testing showed detrimental findings in the group of boxers and this was more apparent in those who had the most bouts. Computer analysis of Tc- $99 \mathrm{~m}$ HMPAO SPECT images showed significantly greater aberrations in cerebral perfusion in the group of boxers than the controls. This study has noted subtle impairment in two aspects of neurophysiology in those young men who receive recurrent head trauma from amateur boxing. The question remains, and is of the utmost importance, as to whether these findings are reversible or will have an effect on subsequent mental, physical, or social wellbeing. It is hoped that the investigators of the $\$ 1.5$ million study in the United States ${ }^{14}$ will follow up their large cohort of boxers to provide a definitive answer.

1 Roberts AH. Brain damage in boxers. London: Pitman 1969.

2 Corsellis JAN, Bruton CJ, Freeman-Browne D. The aftermath of boxing. Physiol Med 1973;3:270-303.

3 Roberts GW, Allsop D, Bruton C. The Occult aftermath of boxing. F Neurol Neurosurg Psychiatry 1990:53:373-8.

4 Tokuda T, Ikeda S, Yanagisawa N. Re-examination of ex- boxers' brains using immunohistochemistry with antibodies to amyloid B protein and tau protein. Acta Neuropathol 1991;82:280-5.

5 Thomassen A, Juul-Jenson P, Olivarius B, Braemer J, Christensen A. Neurological, electroencephalographic and neurophysiological examination of 53 former amateur boxers. Acta Neurol Scand 1979;60:352-62.

6 McLatchie G, Brooks N, Galbraith J, et al. Clinical neurological examination, neuropsychology, electroencephalography and computerised tomographic head scanning in active amateur boxers. $\mathcal{F}$ Neurol Neurosurg scanning in active amate

7 Brooks N, Kupshik G, Wilson I, Galbraith S, Ward R. A neuropsychological study of amateur boxers. $\mathcal{F}$ Neurol Neurosurg Psychiatry 1987;50:997-1000.

8 Jordan BD, Zimmerman RD. Magnetic reasonance imaging in amateur boxers. Arch Neurol 1988;45:1207-8.

9 Haglund Y, Edman G, Murelius O, et al. Does Swedish amateur boxing lead to chronic brain damage? 1 . A retrospective medical, neurological, and personality trait study. Acta Neurol Scand 1990;82:245-52.

10 Haglund Y, Bergstrand G. Does Swedish amateur boxing lead to chronic brain damage? 2. A retrospective study with CT and MRI. Acta Neurol Scand 1990;82;297-302.

11 Haglund Y, Pearson HE. Does Swedish amateur boxing lead to chronic brain damage? 3. A retrospective clinical neurophysiological study. Acta Neurol Scand 1990;82:353-60.

12 Murelius O, Haglund Y. Does Swedish amateur boxing lead to chronic brain damage? 4 . A retrospective neurophysiological study. Acta Neurol Scand 1991;83:9-13.

13 Butler RJ, Forsythe WI, Beverly DW, Adams LM. A prospective controlled investigation of the cognitive effects of amateur boxing. $₹$ Neurol Neurosurg Psychiatry 1993;56:1055-61.

14 Stewart WF, Gordon B, Selnes O, et al. Prospective study of central nervous system function in amateur boxers in the United States. Am $\mathcal{F}$ Epidemiol 1994;139:573-88.

15 Kaste M, Vilkki J, Sainio K. Is chronic brain damage in boxing a hazard of the past. Lancet 1982;ii:1186-8.

16 Ross RJ, Cole M, Thompson JS, Kim KH. Boxers-computerised tomography, EEG, and neurological evaluaputerised tomography, EEG

17 Casson IR, Siegel O, Shan R. Brain damage in modern boxers. $\mathcal{F} A M A$ 1984;251:2663-7.

18 Jordan BD, Zimmerman RD. Computerised tomography and magnetic reasonance imaging comparisons in boxers. $\mathcal{F} A M A$ 1990;263:1670-4

19 Gemmell HG, Evans NTS, Besson JAO, et al. Regional cerebral blood flow imaging: a quantitative comparison of technetium-99m HMPAO SPECT with $\mathrm{C}^{15} \mathrm{O}_{2}$ PET. $\mathcal{F}$ Nucl Med 1990;31:1595-1600.

20 Messa C, Perani D, Lucignani G, Zenorini A, Zito F, Rizzo G. High resolution technetium-99m-HMPAO SPECT in patients with probable Alzheimer's disease: comparison with fluorine-18-FDG PET. $f \mathrm{Nucl} \mathrm{Med}$ 1994;35:210-6.

21 van Zomeren AH. Reaction time and attention after closed head injury. The Netherlands: Swets and Zeitlinger B V-Lisse, 1981 .

22 Teasdale G, Mendelow D. Pathophysiology of head 
injuries. In: Brooks $\mathrm{N}$, ed. Closed head injury. Psychological, social, and family consequences. Oxford: Oxychological, social, and family

23 Newton MR, Greenwood RJ, Britton KE. A study comparing SPECT with CT and MRI after closed head injury. 7 Neurol Neurosurg Psychiatry 1992;55:92-4.

24 Roper SN, Mena I, King, et al. An analysis of cerebral blood flow in acute closed head injury using technetium99m HMPAO SPECT and computed tomography. $f$ Nucl Med 1991;32:1684-7.

25 Barber DC. Registration of low resolution medical images. Phys Med Biol 1992;37:1485-98.

26 Houston AS, Barber DC. Registration of a SPECT brain image with its "nearest normal equivalent" image. Proceedings of the 4th international conference on image processing and its applications. IEEE Conf Publ 1992;354:369-72.

27 Houston AS, Kemp PM, Macleod M. A method for assessing the significance of abnormalities in HMPAO assessing the significance of abnormalities in HMPA
brain SPECT images. 7 Nucl Med 1994;35:239-44.

28 Smith M, ed. Users manual for the Essex Corporation automated performance test system version 5.03. Orlando, Corpotion, 1988.

29 Turnage JJ, Kennedy RS, Smith MG, Baltzley DR, Lane NE. Development of microcomputer-based mental acuity tests. Ergonomics 1992;35:1271-95.

30 Unterharscheidt FJ. Injuries due to boxing and other sports. In: Vinken PJ, Bruyn GW, eds. Handbook of clinical neurology. Amsterdam: North Holland, 1975;23:527-93.

31 Oppenheimer DR. Microscopic lesions in the brain following head injury. $f$ Neurol Neurosurg Psychiatry 1968;31:299-306.

32 Gronwall D, Wrightson P. Cumulative effects of concussion. Lancet 1975;ii:995-7.

33 Gentleman SM, Graham DI, Roberts GW. Molecular pathology of head trauma: altered BAPP metabolism and the aetiology of Alzheimer's disease. Prog Brain Re 1993;96:237-46

34 Buee L, Hof PR, Bouras C, et al. Pathological alterations of the cerebral microvasculature in Alzheimer's disease and related dementing disorders. Acta Neuropathol 1994;87:469-80.

35 Clark C, Carson R, Kessler R, et al. Alternative statistical models for the examination of clinical positron emission models for the examination of clinical positron emission tomography/flurodeox
Metab 1985;5:142-50

36 Clark CM, Ammann W, Martin WRW, et al. The FDG/PET methodology for early detection of disease onset: a statistical model. $f$ Cereb Blood Flow Metab 1991;11:A96-A102.

37 Azari NP, Pettigrew KD, Schapiro MB, et al. Early detection of Alzheimer's disease: a statistical approach using positron emission tomography data. $\mathcal{F}$ Cereb Blood Flow Metab 1993;13:438-47.

38 Fazekas F, Alavi A, Chawluk JB, et al. Comparison of CT, $M R, P E T$ in Alzheimer's dementia and normal ageing. $\mathcal{f}$ Nucl Med 1989;30:1607-15.

39 Wiedmann KD, Wilson JTL, Wyper D, et al SPECT cerebral blood flow, MR imaging, and neuropsychological findings in traumatic head injury. Neuropsychiatry findings in traun

40 Montaldi D, Brooks DN, McColl JH, et al. Measurement of regional cerebral blood flow and cognitive performance in Alzheimer's disease. I Neuro Neurosurg Psychiat 1990;53:33-8.

41 McKeith LG, Bartholomew PH, Irvine EM, Cook J, Adams $\mathrm{R}$, et al. Single photon computerised tomography in elderly patients with Alzheimer's disease and multiinfarct dementia-regional uptake of technetium labelled HMPAO related to clinical measurements. $\mathrm{Br} \mathcal{F}$ Psychiatry 1993;163:597-603.

42 Levin HS, Amparo E, Eisenberg HM, et al. Magnetic reasonance imaging and computerised tomography in relation to the neurobehavioural sequelae of mild and ton to the neurobehavioural sequelae of mild and

43 Ainsworth ME. The relationship between motivation, personality, intelligence and school attainment in a secondary modern school [thesis]. Manchester: University of Manchester, 1965. 